\title{
IMPLEMENTASI PERATURAN DAERAH PROVINSI KEPULAUAN RIAU NO.7 TAHUN 2011 TENTANG PELAKSANAAN PENGARUSUTAMAAN GENDER DALAM PEMBANGUNAN DI PROVINSI KEPULAUAN RIAU TERHADAP KESEJAHTERAAN MASYARAKAT DI KOTA TANJUNGPINANG
} (Studi Kasus pada Dinas Pengelola Keuangan dan Aset Daerah Kota Tanjung Pinang)

\author{
Askarmin Harun \\ Ilmu Pemerintahan Fakultas Ilmu Sosial dan Ilmu Politik \\ Universitas Riau Kepulauan \\ askarmin@ rocketmail.com
}

\begin{abstract}
This study aimed to analyze the compatibility between the implementation of gender mainstreaming is implemented by the Regional Regulation No. 7 Year 2011. This research was conducted at the Department of Financial Management and Asset (DPKAD) city of Tanjung Pinang. This research was conducted using the case study method. The results of this study shows the implementation of gender mainstreaming in the town of Tanjung Pinang. However, the gender mainstreaming only in activities carried out and is not accompanied by a budget allocation so that gender mainstreaming, not in accordance with Regional Regulation No. 7 Year 2011 on Gender mainstreaming is endorsed by the government.
\end{abstract}

Keyword: implementation regulation, $P U G$ and $P P R G$

\begin{abstract}
Abstrak
Penelitian ini bertujuan untuk menganalisis kesesuaian antara penerapan pengarusutamaan gender yang dilaksanakan dengan Peraturan Daerah No. 7 Tahun 2011. Penelitian ini dilakukan di Departemen Pengelolaan Keuangan dan Aset (DPKAD) Kota Tanjung Pinang. Penelitian ini dilakukan dengan menggunakan metode studi kasus. Hasil penelitian ini menunjukkan implementasi pengarusutamaan gender di kota Tanjung Pinang. Namun, pengarusutamaan gender hanya dalam kegiatan yang dilakukan dan tidak disertai dengan alokasi anggaran sehingga pengarusutamaan gender, tidak sesuai dengan Peraturan Daerah No. 7 Tahun 2011 tentang Pengarusutamaan Gender yang disahkan oleh pemerintah.
\end{abstract}

Kata Kunci: peraturan pelaksanaan, $P U G$ dan $P P R G$ 


\section{A. Pendahuluan}

Undang-Undang Dasar 1945 merupakan bentuk peraturan perundang-undangan yang tertinggi, artinya secara teori UUD 1945 merupakan sumber dan dasar bagi setiap bentuk peraturan perundang-undangan lain dibawahnya, seperti misalnya Undang-Undang, Perpu, PP, Perda, dan Perpres. Dengan adanya hal tersebut membawa suatu konsekuensi yuridis bahwa segala jenis peraturan perundang-undangan di bawah UUD 1945 tidak boleh bertentangan dengan amanat yang dimaktubkan di dalam UUD 1945.

Dalam konstitusi Republik Indonesia yaitu Undang-Undang Dasar Negara Republik Indonesia Tahun 1945 dalam pasal 4 ayat (1) dikatakan bahwa Presiden Republik Indonesia memegang kekuasaan pemerintahan menurut Undang-Undang Dasar, sehingga dalam pasal ini apabila kita tafsirkan bahwa pemegang kekuasaan tertinggi di negara RI yaitu presiden kekuasaan yang tidak terbagi dan hanya ada satu pemerintah yang berdaulat sehingga jelas Negara kita pada dasarnya menganut asas sentralisasi/sentralistik.

Namun karena luasnya daerah-daerah di negara kita yang terbagi-bagi atas beberapa provinsi,kabupaten serta kota, maka daerah-daerah tersebut memiliki pemerintahan daerah dengan maksud guna mempermudah kinerja pemerintah pusat terhadap daerahnya sehingga, digunakanlah suatu asas yang dinamakan asas otonomi sesuai dengan yang diatur dalam pasal 18 ayat (2) Undang-Undang Dasar Negara Republik Indonesia Tahun 1945. Maka dari itu pemerintahan daerah menjalankan otonomi seluas-luasnya, kecuali urusan pemerintahan yang oleh undang-undang ditentukan sebagai urusan pemerintah pusat, sehingga dalam hal ini menimbulkan suatu hubungan wewenang antara pemerintah pusat dan pemerintah di daerah.

Untuk mengimplementasikan tugas-tugas berdasarkan amanat UU tersebut sudah barang tentu di perlukan Produk Hukum daerah yang dibuat dalam bentuk Peraturan daerah dimana tertuang dalam pasal 14 undang-undang No 12 Tahun 2011 materi muatan Peraturan Daerah Provinsi berisi materi muatan dalam rangka penyelenggaraan otonomi daerah dan tugas pembantuan serta menampung kondisi khusus daerah.

Peraturan daerah (Perda) merupakan manifestasi dari peraturan perundang-undangan yang lebih tinggi disesuaikan dengan kondisi dan kepentingan masyarakat di daerah. Pemerintah daerah mempunyai tugas untuk menampung aspirasi masyarakat daerah untuk kemajuan dan kemaslahatan masyarakat di daerah disesuaikan dari peraturan perundangundangan di atasnya karena berhasilnya pemerintah daerah dalam konteks demokrasi dan 
otonomi daerah dewasa ini dapat dilihat dari bagaimana pemerintah daerah mampu menampung keinginan masyarakat untuk ditransformasikan dan diformulasikan menjadi kebijakan publik berupa perda yang berpihak pada masyarakat daerah.

Akan tetapi apakah dengan keberadaan perda tersebut kehidupan masyarakat dapat lebih baik lagi, kemudian apakah dengan hal tersebut perempuan bisa dengan mudah untuk beraktualisasi dan berkiprah di ranah publik tanpa ada lagi diskriminasi serta stereotype dari laki- laki. Fenomena hari ini menjadi perhatian dunia bahkan Indonesia terhadap pembangunan yang berbasiskan Gender semakin Besar. Telah lama di ketahui bahwa Hampir diseluruh Negara telah terjadi Diskriminasi Gender Ketidakadilan gender atau diskriminasi gender merupakaan akibat dari adanya system ( struktur ) sosial dimana salah satu jenis kelamin ( laki -laki atau Perempuan ) menjadi korban. Untuk itu diberlakukan alokasi anggaran responsive gender.

Asumsi bahwa anggaran yang responsive gender diperuntukkan bagi masyarakat secara umum, pasti di dalamnya terdapat laki-laki dan perempuan. Hal ini seringkali menjadi alasan pembenaran pemerintah untuk tidak memberikan perhatian khusus untuk kelompokkelompok miskin dan minoritas. Terutama para perempuan ,Padahal meskipun alokasi anggaran itu diberikan kepada semua orang, namun belum tentu dinikmati dengan kapasitas yang setara dan berdampak yang sama bagi semua orang. Faktanya, dampak yang dirasakan perempuan dan laki-laki dari kebijakan anggaran berbeda, umumnya pihak perempuan dirugikan dengan kebijakan anggaran yang netral. Oleh sebab itu, alasan utama diperlukannya anggaran responsif gender dimaksudkan untuk memujudkan kesetaraan antara laki-laki dan perempuan.

Mengacu pernyataan yang di kemukakan Debbie Budlender bahwa anggaran responsif gender adalah sebuah metode analisis anggaran pemerintah yang melihat bagaimana dampak anggaran terhadap perempuan dan laki-laki, anak perempuan dan anak laki-laki pada perbedaan kelompok ekonomi. Adapun tujuan anggaran responsif gender adalah: (a). Meningkatkan efek alokasi anggaran pemerintahan terhadap perempuan dan laki-laki, dan agar mencapai target kebijakan penerimaan dan pengeluaran yang menjadi lebih efektif dalam rangka menghindari kebijakan bias gender yang tidak di ingingkan oleh warga negara. (b). Meningkatkan kesadaran warga negara tentang pentingnya kebijakan gender and development (GAD) dan upaya mempercepat terwujudnya kesetaran dan keadilan gender. (c). Meningkatkan akuntabilitas pemerintah dalam upaya menterjemahkan program dalam 
kebijakan untuk mewujudkan kesetaraan gender melalui komitmen anggaran. (d). Mengubah kebijakan anggaran menjadi responsif gender untuk meningkatkan gender equality.

Dalam hal ini pemerintah makin menyadari pentingnya aspek gender dalam segala bidang pembangunan membawa dampak Positif dalam upaya pengarustamaan gender. Menanggapi hal tersebut, pemerintah sudah mengeluarkan INPRES No 9 Tahun 2000 tentang Pengarustamaan Gender yang bertujan untuk menurunkan kesenjangaan antara perempuan dan laki-laki Indonesia dalam mengakses dan memperoleh manfaat pembangunan serta meningkatkan partisipasi dalam dan pengusaan terhadap proses pembanguan. Melalui Inpres ini muncul kesempatan bagi kemajuan perempuan dan peningkataan kesetaraan gender yang akhirnya diperluas hinga perencanaan dan penganggaran yang inklusif gender.

Kemudian yang diterjemahkan ke daerah-daerah yang ada di Indonesia tak terkecuali Provinsi kepualaun Riau sebagai wujud dari pada perhatian dan keberpihakan pemerintah daerah terhadap permasalahan tersebut. Provinsi Kepulauan Riau atau Biasa dikenal dengan KEPRI merupakan provinsi Baru wilayah ini terbentuk pada tanggal 24 september 2002 berdasarkan Undang- undang nomor 25 tahun 2002. Dalam pelaksananakan pemerintahan di wilayah pemerintah selaku eksekutif bersama Legislatif yaitu Dewan Perwakilan Rakyat Daerah ( DPRD ) yang salah satu tugas nya merancang dan membuat berbagai kebijakan dengan di keluarkanya sebuah peraturan daerah. Dan DPRD Provinsi kepulauan Riau membuat sebuah prodak peratuaran Daerah Seperti yang tertuang didalam peratuaran daerah tersebut yang berdasarkan Inpres Nomer 9 tahun 2000 seluruh Gubernur dan Bupati/walikota Di haruskan melaksanakaan Srtategi Pengarustamaan gender dalam pembagunan Nasional maupun daerah, kemudian Inpres tersebut dioperasionalkan lagi oleh peraturan menteri dalam Negeri Nomer 15 Tahun 2008 tentang pelaksanaan pengarustamaan Gender di Daerah.

Pengarustamaan Gender ( PUG) merupakaan strategi yang dibangun untuk mengintegrasikaan perpektif gender menjadi satu dimensi integral dari perencanaan, penyusunan, pelaksanaan, pemantauaan, dan evaluasi atas kebijakaan dan program pembangunan. Pelaksaanaan PUG harus terefleksikaan dalam proses penyusunan kebijakan yang menjadi acuan perencanaan dan pengaggaran untuk menjamin program dan kegiataan yang dibuat oleh seluruh lembaga pemerintah baik pusat maupun daerah menjadi responsif gender. Perencanaan dan pengaggaran yang responsif gender ( PPRG ) merupakaan perencanaan yang disusun dengan mempertimbangkaan empat aspek yaitu, akses, partisipasi, kontrol, dan manfaat yang dilakuakan secara setara antara perempuan dan laki - laki. Hal ini berarti bahwa perencanaan dan penganggaran tersebut mempertimbangkaan aspirasi, 
kebutuhaan dan permasalahaan pihak perempuan dan laki - laki, baik dalam proses penyusunan maupun dalam pelaksanaan kegiataan.

Berdasarkan kajian teori dan hasil penelitian yang terdapat pada pendahuluan maka dalam penelitian ini hanya terfokus pada Implementasi Perda No.7 Tahun 2011 Tentang Pelaksanaan Pengarusutamaan Gender Dalam Pembangunan Di Provinsi Kepulauan Riau (Di Kota Tanjungpinang), yang mana sesuai dengan isi Perda No. 7 Tahun 2011 Bab III Ruang Lingkup pada pasal 4 yaitu ruang lingkup pengarusutamaan gender meliputi seluruh proses penyusunan perencanaan, pelaksanaan, pemantauan, laporan dan evaluasi kebijakan dan program pembangunan daerah yang dilakukan oleh Pemerintah Provinsi dan Kabupaten/Kota Provinsi Kepulauan Riau serta sektor-sektor swasta dan perguruan tinggi yang menjadi mitra kerjasama dalam pelaksanaan pembangunan di Provinsi Kepulauan Riau, yang mana penulis lebih fokus ke salah satu SKPD di Pemerintahan Kota Tanjungpinang yaitu di Dinas Pendapatan Pengelolaan Keuangan dan Aset Daerah Kota Tanjungpinang yang mana penulis akan meneliti lebih dalam tetang alokasi pelaksanaan anggaran gender di SKPD Terkait pada tahun 2013 apakah sesuai dengan amanat Perda.

\section{B. Tinjauan Pustaka}

Dalam hal ini peneliti mengunakan pendekatan analisis gender karena ketika mengakaji dan mendalami isi dari pada sebuah perda yang diharapakan mampu mencari Efektivitas Implementasi Perda Pengarustamaan Gender Dalam Pembagunan Di Provinsi Kepulauan Riau Terhadap Kesejahteraan masyarakat kota di Tanjung Pinang dimana permasalahan tersebut dapat di kaji secara teliti dan cermat.

Peneliti merasa bahwa dengan mengunakan Analisis Gender merupakan kunci utama dari pengarustamaan gender selain penyadaran adalah analisis gendernya. Adapun tahapan yang dilalui dalam perumusan kebijkaan dengan panengarustamaan adalah, pertama, perencanaan pembuatan dan pelaksanaan, dalam tahapan perencanaan diperlukan data statistic yang terpilih menurut jenis kelamin, kedua, penerapan, penerapan program dan kebijakaan yang responsive gender dapat bervariasi sesuai kondisi setempat, ketiga partisipasi yaitu siapa yang terlibat dan memperoleh manfaat dari kebijakan tersebut. Selajutnya keempat manejemen yaitu pengelompokan keterlibatan laki- laki dan perempuan dalam implementasi kebijakaan dan terakhir pengawasan dan evaluasi yaitu pihak yang akan melakukan evaluasi dan pada tingkatan mana evaluasi dan pengawasan itu dapat dilakukan. 
Dan kemudian peneliti mampu mengambil salah satu muatan yang terkandung didalam sebuah prodak kebijakaan Daerah yaitu terkait pengalokasian anggaran yang responsiv gender, karena menginggat pentingnya peran dan ruang para perempuan agar mampu megakses segala bentuk fasilitas yang diberikan negara melalui pemerintah daerah masing - masing.

Oleh sebab itu sayapun mencoba untuk mengkaji lebih dalam terkait bagaimana Birokrasi Pemerintah Daerah melalui SKPD atau dinas terkait dalam hal ini DPPKAD yang mempunyai peran besar terhadap kebijakaan tersebut. Diharapkan mampu menjadi garda terdepan didalam proses transformasi kebijakaan peraturan daerah yang telah dibuat dan diimplementasikan.

Berikut gambaran dari alur Implementasi sebuah Peraturan Daerah tentang Pengarustamaan Gender dalam pembagunan Di kota Tanjung Pinang Provinsi kepulauan Riau terhadap Kesejahteraan masyarakat, terkait bagaimana pemerintah daerah melalui satuan kerja menjalankan amanat tersebut, didalam proses perencanaan, penyusunan dan pengalokasian Anggaran yang lebih responsiv gender, sehingga masyarakat terutama perempuan merasa tidak didiskriminasikan dalam segala pembagunan menuju masyarakat yang adil dan makmur serta sejahtera.

Gambar II. Bagan Implementasi Perda Gender Nomor 7 Tahun 2011 Tentang Pelaksanaan Pengarusutamaan Gender Dalam Pembangunan Di Provinsi Kepulauan Riau Terhadap Kesejateraan Masyarakat (Di Kota Tanjungpinang)

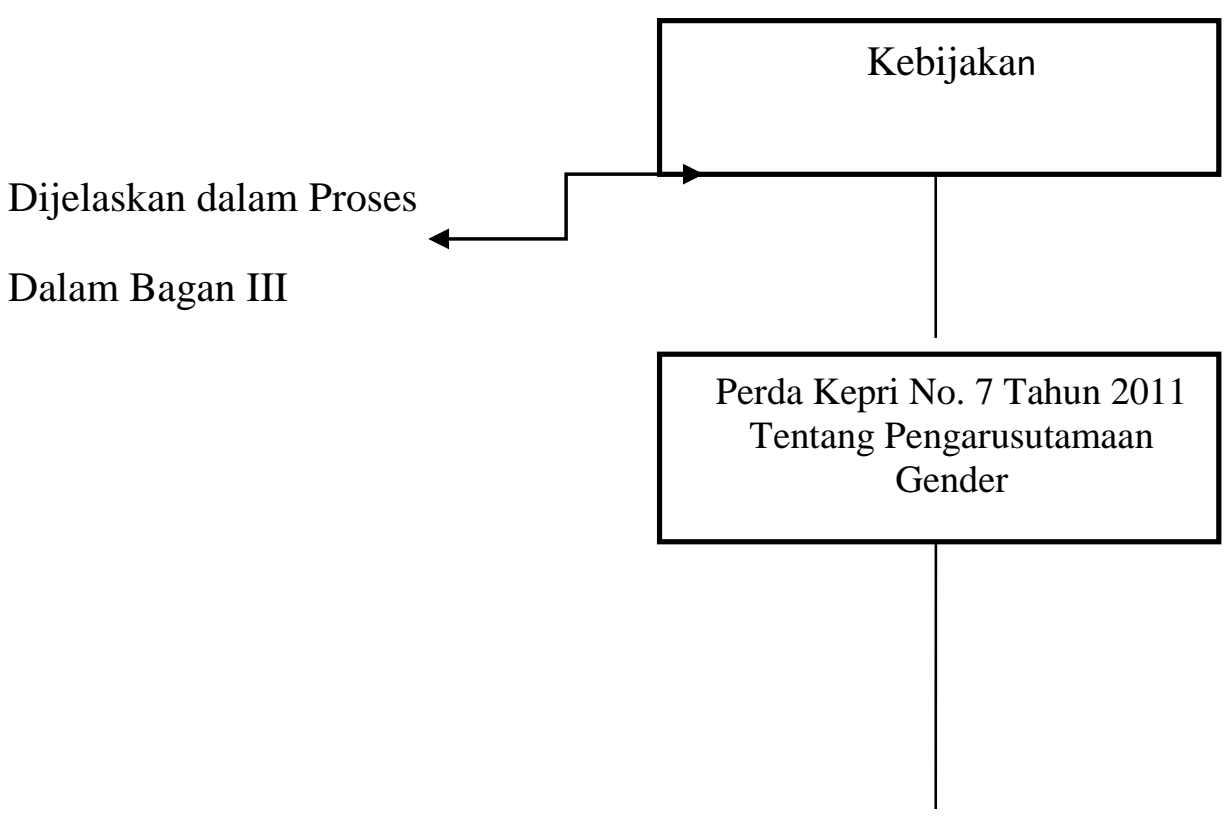




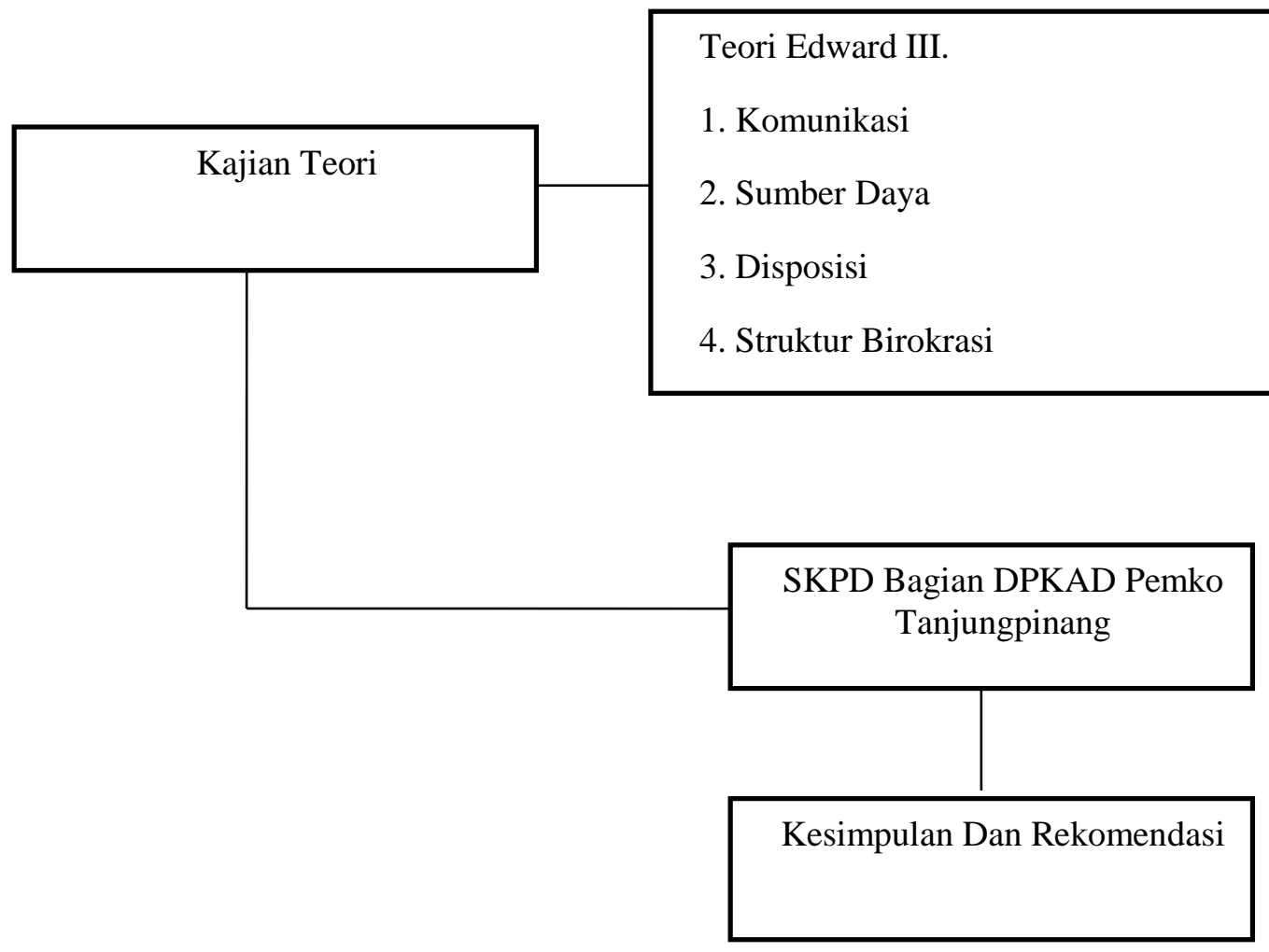

Selanjutnya Proses Kebijakan Publik yang responsive Gender akan dibahas melalui bagan sebagai berikut :

\section{Gambar II. Bagan Proses Kebijakan Publik Responsif Gender}

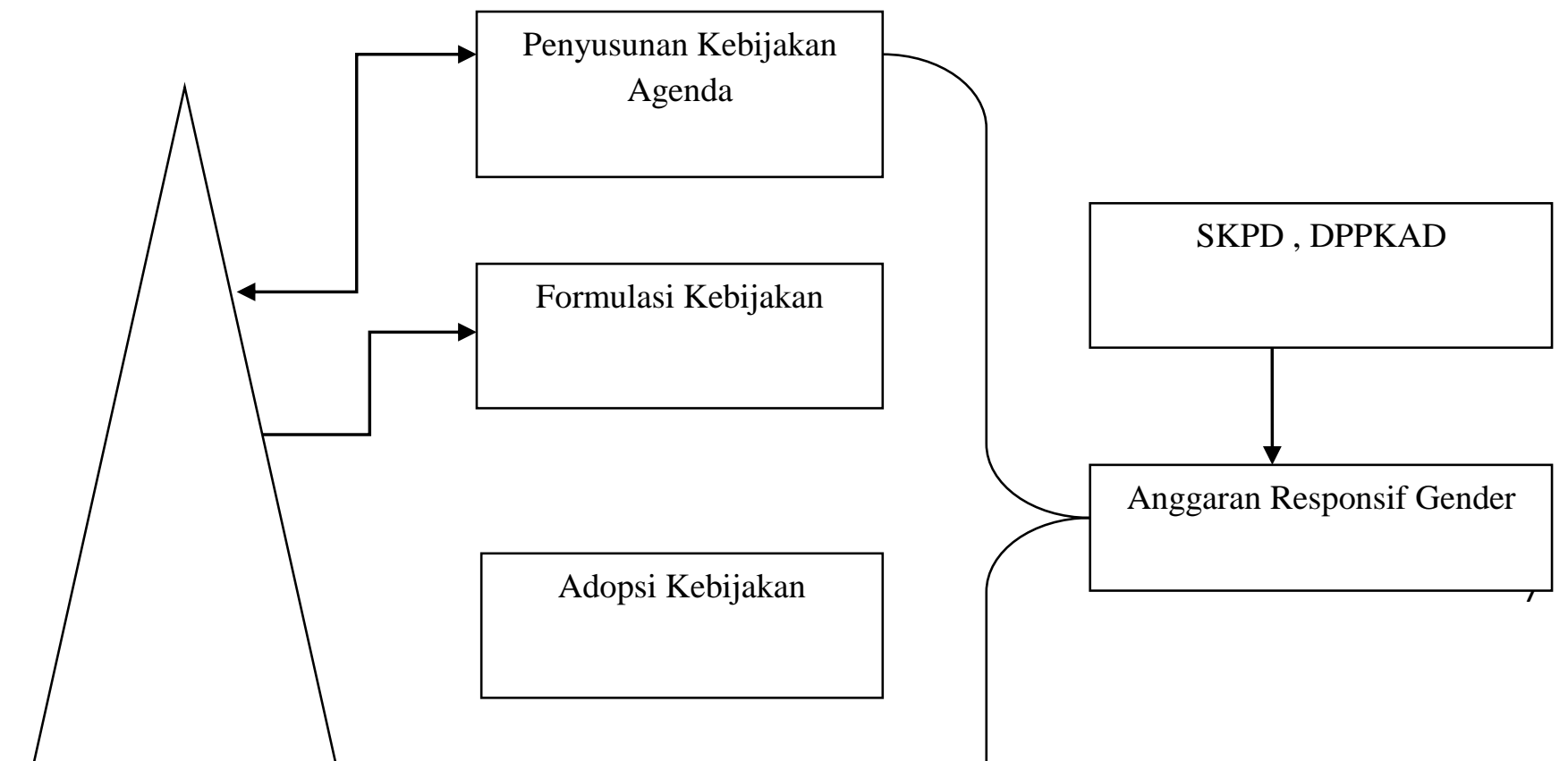


Pemko

Tanjung

Pinang
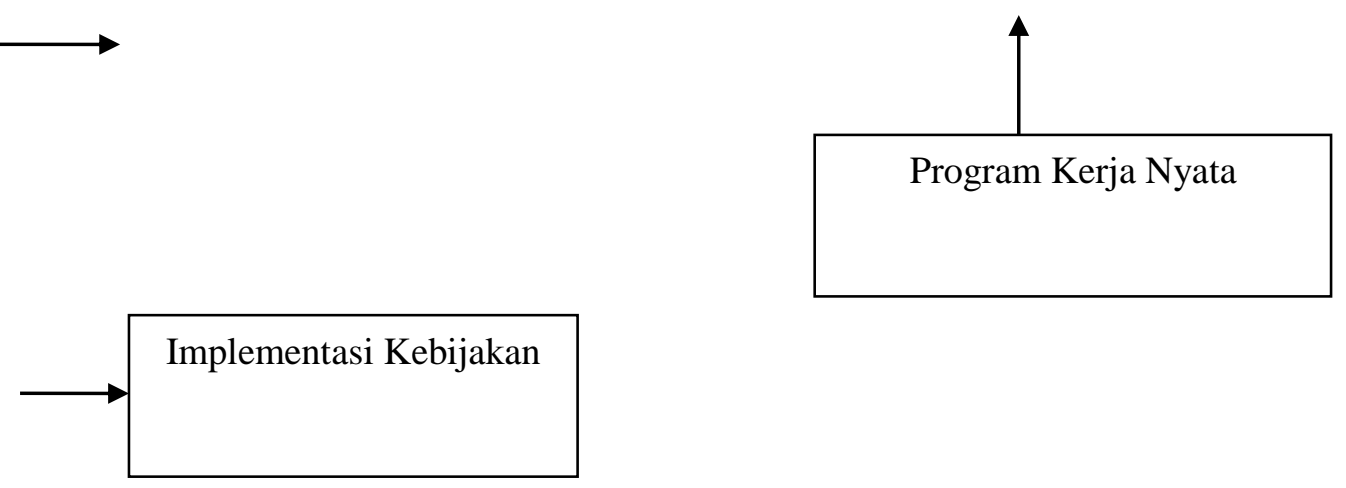

Evaluasi Kebijakan

Artiya; didalam proses kerja kebijakaan pemerintah kota Tanjung Pinang meliputi Tahapan tahapan :

1. Tahap Penyusunan Agenda sebelum sebuah kebijakan di terapakan maka langkah awal dari pada tersebut adalah maslah - maslah tersebut dikelompokan, yang kemudian di olah menjadi sebuah agenda kebijakan.

2. Tahap Formulasi Kebijakaan, masalah yang telah masuk ke agenda kebijakaan kemudian dibahas oleh para pembuat kebijakaan. Masalah - masalah ini didefinisikan untuk kemudian dicari pemecahaan masalah terbaik. Pemecahaan masalah tersebut dari berbagai alternatif atau pilihan kebijakaan yang ada.

3. Tahap Adopsi Kebijakaan, dari sekian banyak alternatif kebijakaan yang ditawarkan oleh para perumus kebijakaan, pada akhirnya salah satu dari alternatif kebijkaan tersebut diadopsi dengan dukungan dari mayoritas, legislatif , konsensus antara direktur lembaga atau keputusan peradilan.

4. Tahap Implementasi kebijakaan, sebuah gagasan, dan usulan beserta ide yang bagus ketika tidak di imolementasikan dengan baik makan akan menjadi sebuah kebijakan yang hanya di pikiran dan catatan saja.Dan kebijakaan yang sudah diambil dilaksanakaan oleh unit - unit administrasi yang memobilsasikan sumberdaya finansial dan manusia. Pada beberapa implementasi kebijakaan mendapat dukungan para pelaksana, namun beberapa yang lain mungkin akan ditentang oleh para pelaksana.

5. Tahap Eavaluasi Kebijakaan, Pada tahap ini kebijakaan yang telah dijalankan akan dinilai atau di eavaluasi, untuk melihat sejauh mana kebijakaan yang dibuat telah 
mampu memecahkan masalah. Kebijakaan publik pada dasarnya dibuat untuk meraih dampak yang diinginkan,Aggaran yang responsif genderpun di harapkan mampu membuat sebuah kebijakaan tepat sasran ketika di terapakan di dalam pelaksanaan nya, hal ini yang akan menjadi bahan evaluasi kedepan di dalam prodak sebuah kebijakan yang telah di jalankan sesuai tahapan - tahapannya.

6. SKPD bagian DPPKAD, yang merupakan lembaga atau instansi yang dirasa mampu dan tepat untuk menerjemahakan dari pada isi sebuah peraturan daerah pengarustamaan gender terkait perencanaan, peyusunan, dan pengalokasian dari alokasi anggaran Pemerintah Daerah yang pro perempuan, artinya tidak ada perbedaan kelas di dalam penerapannya, Dimana sesuai dengan tatakelola keuangan negara dimana proses keuangan tersebut dilaksanakan secara Profesioanal, Akuntabelitas artinya berorentsi pada hasil - hasil, Proposional yang artinya tepat sasaran dan sesuai tinggkat kebutuhan, yang kemudian adanya Keterbukaan atau trasparansi dalam penggelolaan keungan tersebut.

7. Anggaran Responsif Gender, artinya bahwa ketika mengalokasikan anggaran tersebut mampu merespon segala kebutuhan, permasalahan, aspirasi dan pengalamaan perempuan dan laki-laki yang tujuannya untuk mewujudkan kesetaraan gender sehingga pihak perempuan mendapatkan porsi yang tepat dan sesuai dengan kebutuhan.

8. Program Kerja Nyata, maksudnya adalah setelah tahap demi tahap dilasanakan maka apa yang sudah dirumuskan mampu di terjemahkan kedalam sebuah aksinyata yaitu mejadi program kerja nyata, baik dalam bentuk pendampingan kasusistik maupun pelatihan atau peningkatan kesejahteraan masyarakat tanpa mediskriminasikan salah satu daripada jenis kelamin tertentu.

\section{Metode Penelitian}

Jenis penelitian ini termasuk ke dalam jenis penelitian deskriptif kualitatif. Penelitian yang bersifat Deskriptif Kualitatif, yaitu berupaya menggambarkan suatu fenomena yang diteliti secara apa adanya di lapangan. Penelitian deskriptif merupakan suatu metode dalam meneliti status kelompok manusia, suatu objek, suatu kondisi, suatu sistem pemikiran ataupun suatu kelas peristiwa pada masa sekarang yang bertujuan untuk membuat deskripsi, gambaran atau lukisan secara sistematis, faktual dan akurat mengenai fakta-fakta, sifat-sifat serta hubungan antar fenomena yang diselediki (Nizar,2013). 
Hal ini sesuai dengan pendapat Bungin (2010:69) yang menyatakan bahwa format deskriptif kualitatif lebih tepat apabila digunakan untuk meneliti masalah-masalah yang membutuhkan studi yang mendalam, seperti permasalahan implementasi kebijakan publik dimasyarakat. Sedangkan Creswel ( 1998 ) mengatakaan, Bahwa penelitian kulitatif sebagai bentuk suatu gambaran komplek, memilah kata - kata laporan terinci dari pandangan responden dan cenderung mengunakan analisis dengan pendekatan induktif proses dan makna ( prespektif subjek lebih ditojolkan dalam penelitian) kemudian landasan teori dimanfaatkan sebagai pemandu agar fokus penelitian sesuai dengan fakta lapangan.

Metode pengambilan data adalah yang digunakan dalam penelitian ini meliputi :

1. Wawancara, wawancara dilakukan dengan melakukan Tanya jawab dengan pihak - pihak terkait yang dapat memberikan informasi yang berkaitan dengan penelitian yaitu di kantor SKPD terkait. Wawancara yang dilakukan dengan metode bebas terstruktur yang mana peneliti mengajukan pertanyaan kepada pihak interviewee ( pihak yang diwawancarai ) dengan susunan pertanyaan yang sesuai point - point yang telah dirumuskan dalam suasana yang akrab dan kekeluargaan, tetapi tidak menyimpang dari tujuan awal wawancara.

2. Dukumentasi, dukumentasi dilakukan dengan mengumpulkan, mencataat, dan memanfaatkan data yang ada di instansi yang berkaitan dengan penelitian, beberapa dukumen resmi selama periode yang telah ditentukan sehingga akan diperoleh data yang relevan dan objektif.

3. Observasi, Observasi dilakukan dengan mengamati fenomena yang terjadi di lapangan apakah sudah sesuai dengan yang tertulis. Dalam hal ini peneliti mengunakan metode non partisipan.

4. Angket atau Kuisioner, merupakan suatu cara pegumpulan data dengan cara mengajukan beberapa pertanyaan oleh peneliti terhadap beberapa perangkat SKPD beserta masyarakat kota Tanjung Pinang sebagai sample. Disetiap jawaban memiliki nilai yang nantinya akan di olah sebagai data.

5. Studi kepustakaan merupakan kajian kepustakaan melalui buku-buku perpustakaan atau literature, peraturan-peraturan yang berhubungan dengan objek penelitian. Dalam penelitian penulis menelaah teori-teori tentang masalah-masalah di teliti dari berbagai sumber yang merupakaan sarana untuk menganalisis data yang di peroleh.Dengan tetap memperhatikaan 
Hasil dari prose wawancara di lapangan, agar antara kajian kepustakaan dengan jawaban responden mampu di terjemahkan dan di pertangung jawabkan secara ilmiah.

\section{Hasil Penelitian dan Pembahasan}

Pada bagian ini peneliti akan membahas tentang mekanisme pengajuan anggaran sampai dengan laporan pertanggung jawaban untuk pengarustamaan gender sebagai berikut :

1. Didalam Mekanisme pengajuan anggaran yang di terapkan, para pemohon membuat sebuah perencanaan program yang di sertai dengan alokasi perkiraan anggaran yang di tuangkan kedalam sebuah Proposal penggajuan, dimana dari proposal tersebut akan di ketahui secara detail gambaran program yang akan dilaksanakan dan berapa dana yang diperlukan untuk melaksanakan program tersebut. Pengajuan disesuaikan dengan instansi yang terkait. Contoh “ Proposal di masukan kedalam kantor Bagian Umum kemudian di naikan atau di ajukan kepada Walikota, yang kemudian walikota akan memberikan rekomendasi atau disposisi kemana proposal itu di turunkan, setelah itu pihak penerima disposisi tersebut memverifikasi untuk kelayakaan program, selanjutnya bagian Penggelola Keuangan Daerah yang akan mencairkan Dana Kegiatan Tersebut sesuai dengan disposisi yang diterimanya. Untuk lebih memahami alur pengajuannya berikut disajikan contoh mekanisme pada kantor walikota :

Gambar 1: Mekanisme Pengajuan Anggaran

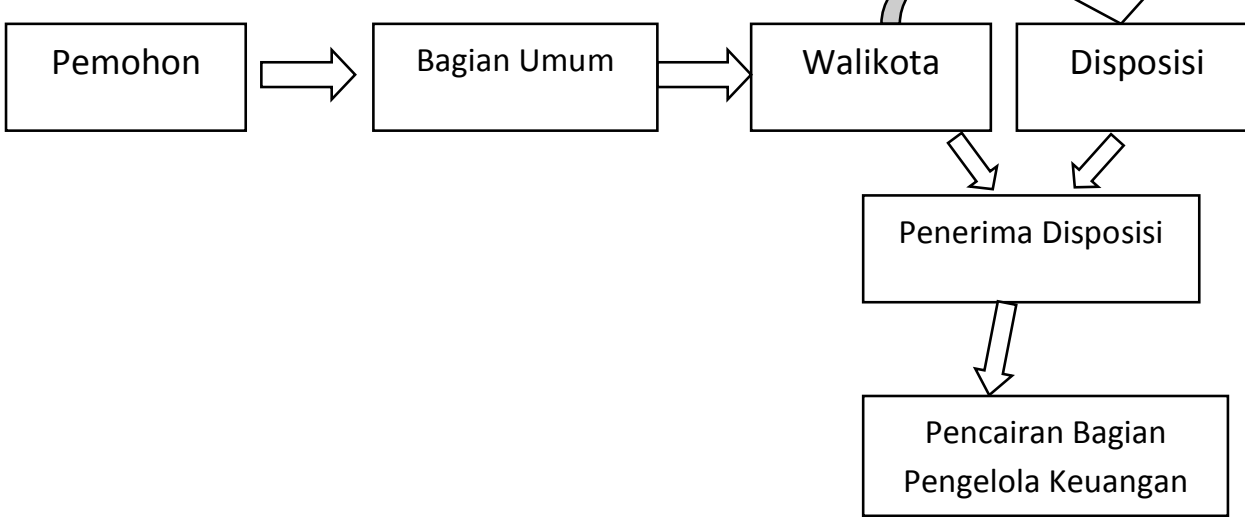

2. Mekanisme Pengalokasiaan Anggaran Terkait dalam hal ini para penentu kebijakaan selalu melihat berapa besar alokasi anggaran dan seberapa mendesak kebututuhan 
tersebut, selain bedasarkaan keputusan walikota ataupun wakil walikota, di beberapa pos-pos anggaran tertentu pihak DPRD pun ikut serta di dalam proses menentukannya tergantung jenis program dan anggaran yang diajukaan.

3. Mekanisme Pertanggungjawaban Anggaran, di dalam pertanggung jawaban dari sebuah pelaksanaan program yang sudah dilaksanakaan mereka yang melaksanaakan atau menyelengarakaan di wajibkan untuk membuat sebuah Lampiran Pertanggung Jawaban dalam bentuk tertulis dan pendokumentasian dari kegiatan tersebut, dan hal itu diberlakukan kepada semuanya baik yang dilaksanakan langsung oleh dinas terkait atau bekerjasama atau bahkan dijalankan sepenuhnya oleh pihak luar atau badan atau organisasi kemasyarakatan, mereka semua diwajibkan dan diharuskan membuat sebuah laporan tertulis. Seperti yang menjadi salah satu bagian Transparansi anggaran pemerintah Daerah.

Bahasan selanjutnya yaitu mengenai pemahaman subtansi Anggaran Responsive Gender di SKPD. Pemahaman Anggaran Responsif Gender di kalangan SKPD sebenarnya mereka paham akan tetapi didalam proses penerapannya yang belum mengerti, itu telihat ketika kita mengajukaan peratanyaan dengan mengunakan metode pertanyaan tertutup " mereka berpendapat bahwa : anggaran responsif Gender merupakaan pelaksanaan dari PUG dalam proses penggangaran yang responsif terhadap kebutuhaan laki- laki dan perempuan dalam rangka mewujudkan keadilan dan kesetaraan gender ( tak berarti harus 50\% laki - laki , 50\% perempuan ).

Hal ini dapat penulis simpulkan dari hasil wawancara penulis dengan kabid Penganggaran DPPKAD Kota Tanjungpinang, Bapak Supari Mengatakan:

“ Pada dasarnya saya tidak terlalu memahami mengenai anggaran yang responsif gende rtersebut karena bagi saya tugas saya adalah memposkan kemana saja anggaran ini diberikan kepada SKPD namun demikian anggaran responsif khusus untuk gender tidak ada".

Dari hasil wawancara diatas dapat disimpulkan bahwa ternyata amanat dari Perda no.7 Tahun 2011 tentang pengarusutamaan gender diprovinsi kepri khususnya dikota Tanjungpinang tidak berjalan sebagaimana mestinya hal itu ditandai dari jawaban wawancara diatas

Selanjutnya Anggaran Kota tanjung Pinang, Dalam hal ini anggaran kota disajikaan kedalam bentuk tabel dimana agar memudah kan para pembaca untuk memahaminya, selain 
dari pada itu agar terlihat secara jelas berapa besar pendapatan dan belanja pemerintah daerah kurun waktu per satu periode masa anggaran.

Tabel 1

Anggaran Kota Tanjung Pinang

\begin{tabular}{|l|l|l|l|}
\hline No & Tahun & PAD & APBD \\
\hline $\mathbf{1}$ & 2013 & Rp. 83.818.759.250 & Rp.1.027.006.993.733 \\
\hline $\mathbf{2}$ & 2012 & Rp.72.356.700.000,00 & RP.824.515.230.636,00 \\
\hline $\mathbf{3}$ & 2011 & Rp.65.623.840.307,00 & Rp.702.599.418.965,00 \\
\hline $\mathbf{4}$ & 2010 & Rp. 46.823.556.174 & Rp. 632.271.231.272 \\
\hline $\mathbf{5}$ & 2009 & Rp.41.954.358.422 & Rp.691.361.505.377 \\
\hline $\mathbf{6}$ & 2008 & Rp.29.654.352.147 & Rp.692.323.824.873 \\
\hline $\mathbf{7}$ & 2007 & Rp.25.965.129.278 & Rp.391.263.278.000 \\
\hline $\mathbf{8}$ & 2006 & Rp.24.422.320.000 & Rp.369.143.767.966 \\
\hline $\mathbf{9}$ & 2005 & Rp.18.633.000.000 & Rp.168.593.000.000 \\
\hline $\mathbf{1 0}$ & 2004 & Rp.16.484.247.038,88 & Rp.150.252.178.038,88 \\
\hline $\mathbf{1 1}$ & 2003 & Rp.15.707.512.021,88 & Rp.162.652.512.021,88 \\
\hline $\mathbf{1 2}$ & 2002 & Rp.7.872.335.077,58 & Rp.188.528.370.077,58 \\
\hline
\end{tabular}

Sumber; DPPKAD kota Tanjung Pinang

Pada tabel 1 : Anggaran Kota Tanjung Pinang diatas hanya ditampilkan keseluruhan anggaran tanpa memperlihatkan pos-pos dari setiap anggaran yang digunakan untuk alokasi apa saja termasuk alokasi responsiv gender. Alokasi Anggaran Responsive Gender, Berdasarkaan hasil dilapanggan pihak pemerintah dalam hal penentu anggaran dari setiap program - program mereka tidak membuat pos khusus untuk responsif gender, akan tetapi semua anggaran yang dibuat bisa di akses oleh semua golongan dan lapisan, karena tolak ukur pemerintah di dalam pengejawantahan responsif gender adalah setiap SKPD di wajibkan 
untuk membuat kegiatan yang melibatkan perempuan, apapun itu bentuk kegiataannnya, jadi walaupun mereka tidak membuat pos gender mereka menilai sudah responsif gender.

Hal ini dapat dilihat dari hasil wawancara dengan Agung S. Hatta Kepala Bidang Kesejahteraan Masyarakat Bappeda KotaTanjungpinang mengatakan:

"Bahwa didalam merealisasikan Perda gender tersebut pemerintah Kota tanjungpinang tidak memberikan porsi anggaran khusus disetiap SKPD mengenai Gender melainkan setiap SKPD di wajibkan untuk melibatkan perempuan dalam setiap kegiatan”. ((09/03/2014, 09.00, Kantor Bappeda Kota Tanjungpinang).

Hal tersebut juga ditambahkan melaui wawancara dengan Ibu Amna Kabid Gender Biro Pemberdayaan Kota tanjungpinang, mengatakan:

"Dalam hal anggaran responsif gender pemerintah kota tidak memberikan alokasi khusus mengenai dana gender tersebut melainkan setiap SKPD diharuskan untuk membuat kegiatan yang responsif gender dan tidak mendekriminasikan salah satu pihak baik laki-laki maupun perempuan dalam setiap program yang dibuat oleh SKPD" (4/04/2014, 14.00, Kantor Biro Pemberdayaan Perempuan Kota Tanjungpinang)

Sehingga dari hasil wawancara diatas dapat penulis simpulkan bahwa tidak ada anggaran khusus yang responsif gender. Melainkan setiap SKPD di haruskan setiap program dan kegiatannya harus responsif gender dimana melibatkan laki-laki dan perempuan disetiap kegiatannya.

Berikutnya mengenai Proses perencanaan penyesuain dan penetapan pengangaran keuangan Daerah yang ada di kota Tanjung Pinang yang digambarkan seperti pada tabel berikut :

Tabel 2

Perencanaan penyusunan dan penetapaan penggangaran keuangan Daerah

\begin{tabular}{|l|l|l|l|l|}
\hline NO & TAHAPAN & PELAKU & OUTPUT & WAKTU \\
\hline
\end{tabular}




\begin{tabular}{|c|c|c|c|}
\hline 1 & $\begin{array}{l}\text { Musrembang desa } \\
\text { atau kelurahaan }\end{array}$ & $\begin{array}{l}\text { Komponen masyarakata( } \\
\text { ketua Rt/ Rw, kepala dusun } \\
\text {,LPM ketua adat, Kelompok } \\
\text { Perempuan, kelompok } \\
\text { pemuda, ormas, pengusaha, } \\
\text { nelayan, tani, lurah } \\
\text { camat,BPD, kepala } \\
\text { puskesmas, LSM dan } \\
\text { pihak2 yang terkait.) }\end{array}$ & $\begin{array}{l}\text { Usulan } \\
\text { kegiatan desa } \\
\text { atau } \\
\text { kelurahaan }\end{array}$ \\
\hline 2 & $\begin{array}{l}\text { Musrembang } \\
\text { kecamatan }\end{array}$ & $\begin{array}{l}\text { Delehasi kelurahan / desa ( } \\
\text { terdapat perwaikilan } \\
\text { perempuan,ormas tingkat } \\
\text { kecamatan BAPEDA, } \\
\text { Perwakilan SKPD, Kepala } \\
\text { Cabang SKPD, kepala unit } \\
\text { pelayanan di tingkat } \\
\text { kecamatan, anggota DPRD } \\
\text { dari daerah pemilihan } \\
\text { kecamatan bersangkutan, } \\
\text { camat dan aparat kecamatan } \\
\text { bersangkutan, LSM, ahli } \\
\text { Profesional ( Jika } \\
\text { diperlukan) }\end{array}$ & $\begin{array}{l}\text { Usulan } \\
\text { kegiatan } \\
\text { kecamatan }\end{array}$ \\
\hline 3 & Forum SKPD & $\begin{array}{l}\text { Delegasi } \\
\text { terdapat } \\
\text { kelompok perwakilan } \\
\text { organisasi sektoral ( missal } \\
\text { dewan pendidkan, IDI dan } \\
\text { IBI untuk forum kesehatan } \\
\text { )kepala SKPD , LSM, } \\
\text { dengan bidang kerja sesuai }\end{array}$ & Renja SKPD \\
\hline
\end{tabular}




\begin{tabular}{|c|c|c|c|}
\hline & & $\begin{array}{l}\text { dengan fungsi SKPD ahli } \\
\text { profesi. }\end{array}$ & \\
\hline 4 & $\begin{array}{l}\text { Musrembang } \\
\text { RKPD } \\
\text { kabupaten/kota }\end{array}$ & $\begin{array}{l}\text { Delegasi musrembangcam, } \\
\text { delegasi forum SKPD, } \\
\text { DPKAD , DPRD, LSM } \\
\text { yang bekerja ditingkat kota / } \\
\text { kabupaten, perguruan tinggi } \\
\text {,perwakilan Bappeda } \\
\text { provinsi, Tim penyusun } \\
\text { RKPD, tim penyusun Renja } \\
\text { SKPD , panitian atau } \\
\text { TimAnggaran Eksekutif } \\
\text { maupun DPRD. }\end{array}$ & $\begin{array}{l}\text { Masukan } \\
\text { Untuk } \\
\text { Dokumen } \\
\text { RKPD }\end{array}$ \\
\hline 5 & $\begin{array}{l}\text { Pembahasan KUA } \\
\text { dan PPAS }\end{array}$ & TPAD dan DPRD & $\begin{array}{l}\text { Dokumen } \\
\text { KUA dan } \\
\text { PPAS }\end{array}$ \\
\hline 6 & $\begin{array}{ll}\text { Penyusunan } & \text { RKA } \\
\text { SKPD } & \end{array}$ & SKPD & $\begin{array}{l}\text { Dokumen } \\
\text { RKA SKPD }\end{array}$ \\
\hline 7 & $\begin{array}{l}\text { Penyusuan } \\
\text { RAPBD } \\
\text { kompilasi dari } \\
\text { RKA ) }\end{array}$ & TAPD & $\begin{array}{l}\text { Dokumen } \\
\text { RAPBD }\end{array}$ \\
\hline 8 & $\begin{array}{l}\text { Pembahasan } \\
\text { RAPBD di DPRD }\end{array}$ & TAPD dan DPRD & APBD \\
\hline 9 & Evaluasi Gubernur & Tim Evaluasi Gubernur & $\begin{array}{l}\text { APBD yang } \\
\text { lolos evaluasi } \\
\text { dan siap dibuat } \\
\text { Perda }\end{array}$ \\
\hline
\end{tabular}




\begin{tabular}{|l|ll|l|l|l|}
\hline 10 & $\begin{array}{l}\text { Penerbitan Perda } \\
\text { APBD }\end{array}$ & Pemda dan DPRD & Perda APBD & \\
\hline
\end{tabular}

Sumber: Diolah, DPRD/Askar

Pada tabel 2 diatas bisa disimpulkan bahwa pada perumusan peraturan daerah (Perda) melibatkan semua pihak yang terkait guna dalam penyusunannya benar-benar adalaah sebuah peraturan yang dibutuhkan dan dapat membantu kesejahteraan masyarakat.

\section{E. Perencanaan Penggangaran yang Responsif Gender}

Artinya adalah bahwa di dalam proses perencanaan seperti yang tertuang didalam amanat Perda PUG provinsi kepulauan Riau, perencanaan responsive Gender dilakukan untuk menjamin keadilan dan kesetaraan bagi perempuan dan laki - laki dalam aspek akses, partisipasi, control dan manfaat pembaguanan. Perencanaan dibuat dengan mempertimbangkan aspirasi, kebutuhan, permasalahan, dan pengalaaman perempuan dan laki - laki baik dalam proses penyusunannya maupun dalam pelaksanaan kegiatan. Dalam konteks perencanaan Daerah, Penggangaran responsive Gender mampu direfleksikan dalam dokumen RPJMD, RKPD, renstra SKPD dan Renja SKPD. Dan diharapkan dengan adanya sistem penganggaran yang responsive gender ini tata kelola dan pengalokasiannya mampu di terapakan sesuai sasaran, tidak ada unsur diskriminasi antara Perempuan dan laki - laki di didalam mengaksesnya. Anggaran responsif gender ( $A R G$ ) merupakaan salah satu instrumen untuk menganalisa anggaran agar lebih tepat sasaran dengan mengidentifikasi penerima anggaran tersebut. Sejalan dengan itu Ronald Sharp ( 2004), mengidentifikasi anggaran responsif gender secara diplomatis bahwa : "Bukanlah anggaran yang terpisah bagi laki - laki dan perempuan, tetapi srategi menintegrasikan isu gender ke dalam proses penggangaran, menerjemahkan komitmen pemerintah untuk mewujudkan kesetaraan gender ke dalam komitmen anggaran. Terdiri atas seperangkat instrumen untuk melihat dampak belanja dan penerimaan pemerintah terhadap Gender. '

Meskipun demikian anggaran responsif gender masih terbilang awam bagi masyarakat sendiri. Akan tetapi sejak pemerintah Provinsi Kepualauan Riau mengetok palunya dan menerapakan Perda pengarustamaan Gender, dan hal itu di perkuat oleh penetapan keputusan Menteri dalam Negeri No. 132 Tahun 2003 yang menetapkan bahwa seluruh pembiayaan yang diperlukaan untuk pelaksanaan pengarustamaan gender didaerah - daerah dibebankan ke dalam APBN dan APBD untuk masing - masing provinsi, kabupaten, dan kota sekurang- 
kurangnya 5\% dari APBD provinsi, kabupaten dan kota. Kemudian diperbaruhi dengan peraturan menteri dalam Negeri No.15 tahun 2008.

Berdasarkaan peraturan dalam Negeri nomor 15 tahun 2008 terdapat pergeseran kosep mengenai pembiayaan pengarustamaan gender di daerah. Dimana didalam sebuah keputusan menteri dalam Negeri No 132 Tahun 2003 menetapkaan pembiayaan pengarustamaan gender minimal 5\% sedangkaan peraturaan dalam Negeri no 15 tahun 2008 tidak ada batas minimum untuk pengarustamaan gender. Karena, untuk responsiv terhahadap gender tidak ada batas minimum atau penggangaran yang dibatasi. Akan tetapi pada peraturaan menteri dalam Negeri No 15 Tahun 2008 justru menyeluruh pengangaran diperuntukaan untuk penagurustamaan gender. Karena dengan itu anggaran bisa lebih luas dinikmati sesuai dengan pembangunan tidak berdasarkan jenis kelamin namun anggaran tersebut dapat dirasakan untuk meningkatakan kualitas hidup.

Tidak ada lagi pembatas bagi masyarakat untuk mengakses dana tersebut terutama perempuan yang selama ini masih mengalami diskriminasi untuk mengunakan dan memanfaatkan semua fasilitas publik. Dan Pemerintah Provinsi Kepualauan Riau mampu menerjemahkannya ke dalam sebuah peraturan Daerah No 7 Tahun 2011 dimana, perencanaan dan penganggran yang responsif gender melalui program kerja yang nyata di pemerintah Daerah Kota Tanjung Pinang yang nota bene menjadi Ibu kota Provinsi Kepulauan Riau.,

\section{F. Pembagunan Daerah Yang Responsive Gender}

Pembagunan Daerah yang Responsif gender di maksudkan bahawa di dalam proses pembagunan di segala Bidang mampu mengimplementasikan isi dari pada sebuah peraturan daerah terkait dengan pengarustamaan Gender, ada unsur pemantauan dan evaluasi di dalam pengerjaan serta sesuai dengan bidang dan fungsi masing- masing tanpa membeda bedakan perempuan dan laki-laki. Sistem pembaguanan Nasioanal bertujuan untuk mendukung koordinasi antar pelaku pembagunan, menjamin terciptanya integritas, singkronisasi dan sinergi baik antar daerah, antar ruang, antar waktu, antar fungsi pemerintah maupun antar pusat dan daerah, menjamin keterkaitan dan konsistensi antara perencanaan, penggangaran, pelaksanaan dan pengawasaan, mengoptimalkan partisipasi masyarakaat seta menjamin tercapainya pengunaan sumberdaya, secara efisien, efektif berkeadilan dan berkelajutan. Dalam rangka melaksanakan pembangunan yang berbasis serta responsive gender. 
Hal ini dapat dilihat dari hasil wawancara dengan Andrianyah Staff Gender di Badan Pemberdayaan Perempuan KotaTanjungpinang mengatakan:

"Bahwa didalam Implementasi Perda Kepri tersebut mengenai Gender maka diharapkan dapat menjadikan sebuah agenda kesetaraan kesamaan antara laki-laki dan perempuan di Kota Tanjungpinang. ((09/03/2014, 09.00, Kantor Bappeda Kota Tanjungpinang).

Namun demikian dari hasil wawancara diatas bertolak belakang dari realitas yang penulis temukan dilapangan kesetaraan dan Kesamaan sesuai dengan amanat Perda nomor 7 tahun 2011 dikota Tanjungpinang ternyata belum dinikmati sepenuhnya oleh perempuan yang ada di Kota tanjungpinang hal ini dapat dilihat dari jalannya program dan pembangunan yang rata-rata keterlibatan perempuannya sangat minim dari berbagai macam aspek pembangunan

\section{G. Pelaksanaan Perda dan Anggaran Responsiv Gender}

Didalam proses pelaksanaan sebuah Peraturan pemerintah Daerah di perlukaan beberapa hal agar peraturan tersebut dapat dijalankan dengan tepat dan pastinya sesuai rencana. Perda yang telah disahkan oleh pemerintah Provinsi kepulauan Riau, yang kali ini di terjemahkan dan sedang berusaha di implementasikan oleh kota Tanjung Pinang dalam hal Pengarustamaan Gender terkait Anggaran yang Responsif Gender, dengan berlandaskan sebuah kondisi yang dinilai masih terbatas tidak membut kota Tanjung Pinang yang nota bene juga menjadi ibu kota provinsi Kepri tersebut.

Hal itu dapat terlihat ketika peneliti turun dan melakukan pengumpulan data bagaimana komunikasi sanggat berpengaruh artinya, apa ketika sebuah peraturan daerah tidak terkomunikasikan dengan baik niscaya akan dapat diterapkan, dalam hal ini kegiatan yang berbentuk sosialisasi kepada masyarakat dijalankan terus guna menerangkan dan mendidik mereka agar paham dengan prodak-rodak pemerintah. Bagaimana pembuatan dan penerapanya di tataran bawah agar tidak terjadi mis komunikasi, karena tidak semua lapisan masyarakat itu paham akan pengarustamaan Gender yang selama ini dijalankan pemerintah, itu terbukti pada lembaran pertanyan peneliti poin 8 dan 9 yang dimana menyakaan

\footnotetext{
“Apakah saudara pernah mendengar Pengarustamaan Gender? Dan Apakah saudara mengetahui tentang Perda Pengarustamaan Gender No 7 Tahun 2011 Pemprov Kepri? Mereka menjawab Tidak tau dan tidak Mengerti karena tidak pernah mendengar dan mendapat informasi tersebut. (jawaban itu diperoleh dari warga masyarakat dan salah satu aktivis Pengerak PKK Kota )".
} 
Berbeda halnya dengan jawaban yang di berikaan oleh kalangan akademisi, Mereka menjawab tau dan mengerti bahkan beberapa menambahkan" bahwa Pengarustamaan Gender itu merupakaan sebuah srategi untuk mengevaluasi suatu kebijakaan dan program di ranah politik, ekonomi, sosial dan budaya dapat terwujud keadilan gender. Artinya apa bahwa komunikasi sanggatlah penting dalam penyampaian sebuah gagasan dan program serta informasi apapun itu. Kemudian Sumberdaya dan disposisi, dalam hal ini antara sumberdaya dan disposisi menjadi satu kesatuan yang mana di dalam melakukan sebuah kebijakaan untuk memberikaan keputusan terkait anggaran pemerintah dalam hal ini adalah walikota ataupun Kepala Dinas, mereka diharapkan mampu menerapkaan kebijakannya dengan tepat dan sesuai prosedur dan mekanisme yang berlaku.

Berdasarkaan lembar pertanyaan pada point 23 menerangkan bahwa yang berwewenang dalam menentukaan perencanaan dan pengalokasian Anggaran Daerah adalah mereka Tim Anggaran yaitu Sekda dan Timnya, serta Beberapa Dinas Bappeda dan DPPKAD melalui rapat anggaran dengan Legislatif, artinya mereka tidak serta merta hanya asal - asalan didalam membuat sebuah kebijakaan tersebut. Akan tetapi mereka masih menganggap untuk responsif gender tidak harus membuat pos anggaran sendiri melainkan tetap includ dengan anggaran yang sudah ada tapi proses pelaksanaanya yang diatur dan diawasi secara langsung walaupun beberapa kegiatan dijalankan oleh pihak ketiga pihak dinas terkait tetap campur tanggan tanpa menguarangi taggung jawab dari pelaksana pogram tersebut.

Selain itu Struktur Birokrasi yang jelas pun juga dapat memudahkan didalam proses artinya masing-masing birokrasi sudah paham akan tugas dan fungsinya. Dan komitmen pemerintah menjadi salah satu syarat utama untuk proses implementasi anggaran responsif gender tersebut karen apabila pemerintah sudah berkomitmen maka untuk mengimplementasikaan anggaran responsif gender akan lebih mudah untuk mewujudkan ARG lebih baik. Hal Tersebut Menjadi landasan utama pemerintah untuk membuat sebuah keputusan yang tertuang dalam SK walikota tahun 2013 dan SK sekretaris daerah kota tanjung pinang No.26 tahun 2012 dimana terkait peraturan daerah No 7 tahun 2011 harus diterjemahkan dan dibuat Rencana Tindak lanjut yang tepat sasaran. Artinya kota tanjung Pinang memang serius utuk mengimplementasikan Perda Tersebut walaupun masih ada kekurangan.

Contohnya di kota tanjung pinang sendiri yang menduduki kepala bagian badan Pemberdayaan Perempuan dan Keluarga Berencana masih dijabat oleh laki - laki, Maka Ironis dalam pembagunan badan perempuan sendiri tidak ada, perempuanlah yang 
seharusnya menduduki kepala tersebut karena perempuan dinilai lebih memahami untuk permasalahaan perempuan. Akan tetapi beberapa fasilitas umum yang di peruntukaan perempuan sudah mulai kelihatan, hal tersebut terdapat di salah satu tempat rekreasi keluarga tepatnya di kebun Binatang di samping mushola berdiri sebuah bagunan yang diperuntukaan bagi ibu-ibu menyusui bayinya, artinya ruang privasi menyusui sudah mulai di berlakukan, selain itu menurut kesaksian langsung oleh seorang mahasiswi bahwa kesetaraan itu juga sudah mulai terlihat dimana yang dulunya peserta seminar, pelatihan keterampilan Home Industri yang di adakan pemerintah itu kebanyakaan laki- laki kai ini sudah mulai rata bahkan sebagian besar hampir 75\% adalah perempuan, hal itu menandakan bahwa perkembangan perempuan sudah mulai di perhitungkan diranah Publik. Oleh sebab itu kegiatan - kegiatan tersebut bisa di kategorikan sebagai bentuk kegiatan yang responsif gender mulai dari keterlibatan peserta dan penyerapan anggaran pun sudah di salurkan dalam hal peningkatan kemampuan sumber daya manusia seperti yang tetuang di dalam amanah perda Pengarustamaan Gender.

Terdapat beberapa ambatan didalam proses implementasi sebuah Peraturan di masyarakat, mulai dari lemahnya sosialisasi ke kalangan Bawah, Bentuk komunikasi, dan kurang pahamnya dengan prodak tersebut, hal itu terlihat ketika penulis melakukan pengambilan data dilapangan, berusaha melakukan beberapa pertayaan terkait apa saja kebijakaan pemerintah yang telah di buat, kemudian saya mengajukan juga pertanyaan apakah pernah mendengar dan mengetahui tentang Peraturan Daerah Provinsi Kepulauan Riau No 7 Tahun 2011 tentang Pengarustamaan Gender, Dari 11 Orang yang di jadikan sempel hanya 3 yang mengetahui dan mengerti akan isi dari sebuah kebijakaan tersebut, akan tetapi ketika di singgung soal Anggaran Responsif Gender mereka tidak Paham anggran yang seperti apa dan Bagaimana Bentuknya. Karena hal itu terlihat pada lembar pertanyaan yang di kosongkan. Dari kondisi tersebut sudah jelas bahwa walaupun mereka sudah melakukan peraturan tersebut masih banyak masyarakaat yag belum paham dan menyadari jika pemerintah sudah mengeluarkaan kebijakaan tersebut. Hal itu sangat ironis di mana pemerintah sudah gencar melakukan program - program yang dapat digunkan untuk penyetaraan gender akan tetapi tidak di imbangi dengan pemahaman di masyarakaat akan apa itu responsif gender dan apa itu sendiri Gender. Artinya antara pemerintah dan masyarakat masih terlampau jauh jaraknya terkait akses informasi.

\section{H. Kesimpulan}


Pengarustamaan Gender merupakan program pembangunan yang di canangkan dan diwacanakan oleh pemerintah pusat dalam rangka meningkatakan kualitas perempuan dan memberikaan ruang gerak bagi perempuan yang selebar - lebarnya. Gender sebenarnya tidak hanya berhenti pada perbedaan jenis kelamin saja, melainkaan sebuah konsep yang mengacu pada peran - peran dan tanggung jawab laki-laki dan perempuan yang terjadi akibat dari dan dapat berubah oleh keadaan sosial dan budaya masyarakat. Akan tetapi, kesenjangan dan diskriminasi di ruang publik masih sering terjadi sehingga, menteri pemberdayaan dan Presiden mengeluarkan INPRES No 9 tahun 2000 guna memenuhi kesetaran Gender tersebut.

Kota Tajung Pinang adalah Ibu kota Propinsi yang merupakan salah satu kota di Indonesia yang sudah melakukan dan mengutamakaan pengarustamaan Gender. Terkait dengan anggaran Responsif Gender yang di lakukan pemerintah, di dalam proses penganggaran tersebut pemerintah tidak membuat pos-pos tersendiri artinya pemerintah tidak menyediakaan anggaran khusus kepada perempuan, akan tetapi mereka selalu melibatkan perempuan di setiap kegiatan, dimana setiap SKPD diwajibkan untuk membuat 1 atau 2 kegiataan yang melibatkan perempuan. Dan salah satu bentuk komitmen pemerintah kota Tanjung Pinang mengeluarkan peraturan walikota dan sekertaris Daerah guna pemanfaatan dan pelaksanan pengarustamaan Gender di kota tersebut. Terkait penyerapan anggaran para pelaksana program bisa langsung berhubungan dengan dinas terkait dengan mekanisme dan posedur yang sudah ada.

Walaupun pemerintah Provinsi Kepulauan Riau dan Kota Tanjung Pinang sudah membuat dan melaksanakan hal tersebut akan tetapi berdasarkan data yang ada dilapangan dan analisa saya sebagai peneliti bahwa prodak tersebut kurang optimal, artinnya masih di perlukan ruang untuk menyempurnakan dan sosialisasi peraturan tersebut belum di pahami dan dimengerti sampai pada tingkatan bawah. Banyak masyarakat yang tidak tau dan tidak mengerti akan keberadaan dan isi daripada perda, terkait salah satu amanah tersebut adalah bagaimana menjalankan anggaran yang responsif gender, hal ini hanya kalangan tertentu saja yang mampu mengaksesnya. Karena hal itu terbukti banyaknya kelemahan di lapangan akan pelaksanan pembangunan dan peningkatan kualitas masyarakat. Diharapkan dengan adanya cacatan ini pemerintah bisa memperbaikinya sehingga terwujud sebuah pemerintahan yang good goverment. 


\section{Daftar Pustaka}

Afifudin, 2013. Pengantar Administrasi Pembangunan, Konsep Teori Dan Implikasinya Di Era Reformasi, Bandung : Alvabeta Cv. Bandung.

Arivia, Gadis, 2003. Filsafat Persfektiffeminis, Jakarta, YJP.

Budiman, Arief, 1985. Pembagian Kerja Secara Seksual, Sebuah Pembahasan Sosiologis Tentang Peran Wanita Di Dalam Masyarakat, Jakarta, PT. Gramedia.

Bungin, Burhan, 2010. Penelitian Kualitatif Komunikasi, Ekonomi, Kebijakan Publik, dan Ilmu Sosial Lainnya, Jakarta, Kencana Prenada Media Group.

Darwin,Muhajir,2005.Negara Dan Perempuan, Reorentasi Kebijakan Publik,Jogjakarta,Media wacana

Dezin, N.K and Yvona, S.L,2009, Handbook of Qualiti reseacrh.( diterjemahkan oleh Dariyatno).:Jogjakarta, Pustaka Pelajar

Dye, Thomas R.,1992. Understanding Public Policy. Englewood Cliffs: Prentince Hall Inc.

Dunn, N.William, 2003. Analisis Kebijakan Publik, Yogyakarta , Gadjah Mada University Press.

Fakih, Massour, 1999 (1996). Analisa Gender Dan Transformasi Sosial, Yogyakarta: Pustaka Belajar.

Gandhi, Mahatma, 2002. Kaum Perempuan Dan Ketidak Adilan Sosial, Yogyakarta: Pustaka Belajar.

Idrus, Muhamad, 2009. Methode Penelitian Ilmu Sosial, Yogyakarta: Gelora Aksara Pratama. Iskandar, 2009. Metodologi Penelitian Kualitatif, Jakarta, Gaung Persada Press.

Indarr, Henny, 2011. Pemiskinan Perempuan Dalam Wujud Karya Ilmiah Konferensi Perempuan, Bulaksumur Yogyakarta.

Indarr, Henny, 2012, Akuntansi sector Publik Dalam Rangka Peningkatan Kesejahteraan Perempuan Lokalisasi kabupaten / Kota ( Pembagunan Perempuan nasional - local ) dalam wujud karya Ilmiah Jurnal Ekonomi UIB,Blitar.Java

Indra , Bastian,2010.Akuntansi sector Publik,erlangga,PT.Aksara Pratama. 
Jones. PP, 2010. Penghantar Teori-Teori Sosial, Jakarta Pusat : Yayasan Pustaka Obor Indonesia.

Labolo Muhadam, 2011. Memahamhi ilmu Pemerintahan Suatu Kajian Teori Konsep Dan Pengembanganya, Jakarta : PT. Raja Grafindo Persada,

Lumbatobing, Dina, 2000. Pengenalan Gender, Medan, Persada.

Muttaqin, Dkk, 2009. Mosel Pemberdayaan Pranata Sosial Dalam Pembangunan Konflik, Jakarta: Raja Grafindo Persada.

Nizar, Moh, 2011. Teknik Dan Ilmu Pengetahuan Statistik Dan Penelitian, Ghalia Indonesia

Ndraha, Taliziduhu,2003. Kybernology (Ilmu Pemerintahan Baru), Jilid1, Yogyakarta, PT Rineka Cipta.

Nugroho Riant D., 2004. Kebijakan Publik, Formulasi, Implementasi, dan Evaluasi, Jakarta, PT Elex Media Komputindo.

Nugroho, Rian, 2003. Reinventing Pembangunan (Menata Ulang Pradigma Pembangunan), Jakarta : Kelompok Gramedia.

Nugroho, I Dan Rochimin Dahuri, 2004. Pembangunan Wilayah Perspektif Ekonomi Sosial Dan Lingkungan, Jakarta : LP3SE

Nugroho, Rian, 2008. Gender Dan Administrasi Publik (Studi Tentang Kuantintas Kesetaraan Gender Dalam Administrasi Public Indonesia Pasca Reformasi 19982002), Yogyakarta : Pustaka Belajar.

Parson Wayne. Edward Elgar, 2006. Public Policy Penghantar Teori Dan Praktik Analisa Kebijakan, Jakarta. Kencana.

Ratna Megawani, 1999. Membicarakan Berbeda Sudut Pandang Baru Tentang Relasi Gender, Bandung. Mizan.

Ritonga,Irwan Taufiq,2010, Akuntansi Pemerintahan Daerah,PascaSarjana UGM.Jogjakarta

Salim, Agus, 2002. Perubahan Sosial Sketsa Teori Dan Refleksi Methodology Kasus Indonesia, Jogyakarta: Wacana.

Sedardamayanti,2003.Good Governance ( kepemerintahaan yang baik) Dalam Rangka Otonomi Daerah Upaya membagun organisasi efektif dan efisien melalui restrukturisasi dan pemberdayaan, Bandung, Mandar Maju

Surya Brata, Sumadi, 1995. Methode Penelitian, Jakarta: Raja Grafindo Persada.

Taringan, R, 2005. Perencanaan Pembangunan Wilayah, Jakarta. Bumi Aksara.

Vreede, Cora, 2008. Sejarah Perempuan Indonesia Gerakan Dan Pencapaian, Jakarta. Komunitas Bambu. 